\title{
Morphine stimulates prolactin release in normal but not in castrated male rats
}

\author{
P. Limonta, F. Piva, R. Maggi, D. Dondi, M. Motta and L. Martini \\ Department of Endocrinology, University of Milano, 21, Via A. del Sarto, 20129-Milano, Italy
}

\begin{abstract}
Summary. Morphine (200 $\mathrm{g} / \mathrm{rat})$ was injected intraventricularly (i.v.t.) into normal and into long-term castrated ( 4 weeks) adult male rats. Animals were killed 10, 20, 40 and $60 \mathrm{~min}$ after treatment. In normal animals, the treatment with morphine resulted in a significant increase of serum prolactin concentrations at all time intervals considered. However, the i.v.t. injection of $200 \mu \mathrm{g}$ morphine/rat into castrated rats did not exert any significant effect on prolactin release at any time interval considered. When morphine $(200 \mu \mathrm{g} / \mathrm{rat})$ was administered i.v.t. together with the specific opioid receptor blocker naloxone $(7.5$ or $15 \mu \mathrm{g} / \mathrm{rat})$ the stimulatory effect of morphine on prolactin release was diminished at $10 \mathrm{~min}$, and totally blocked at $20 \mathrm{~min}$. Naloxone given alone did not influence serum prolactin concentrations.

The results suggest that the presence of endogenous androgens is essential to permit the stimulatory effect of morphine on prolactin release.
\end{abstract}

\section{Introduction}

The administration of morphine, of the endogenous opioid peptides, and of their synthetic analogues is followed by a stimulation of prolactin release (for references, see Meites, Bruni, Van Vugt \& Smith, 1979; Morley, 1981; Clement-Jones \& Rees, 1982). It has also been demonstrated that specific opioid antagonists (e.g. naloxone and naltrexone) may prevent the rise of prolactin secretion induced by the opioids (Rivier, Vale, Ling, Brown \& Guillemin, 1977; Chihara, Arimura, Coy \& Schally, 1978; Kato, Iwasaki, Abe, Ohgo \& Imura, 1978; Meites et al., 1979; Koenig, Mayfield, Coppings, McCann \& Krulich, 1980; Panerai, Casanueva, Martini, Mantegazza \& Di Giulio, 1981; Van Vugt, Sylvester, Aylsworth \& Meites, 1981; Kato et al., 1982). Some authors have also found that opioid antagonists may reduce basal serum concentrations of prolactin (Meites et al., 1979), but this finding has not been confirmed by others (Martin, Tolis, Woods \& Guyda, 1979; Mioduszewski, Zimmerman \& Critchlow, 1982; Giudici et al., 1984).

Data have also accumulated that suggest that brain opioids may be involved in the control of gonadotrophin secretion (for references, see Meites et al., 1979; Morley, 1981; Clement-Jones \& Rees, 1982; Kalra \& Kalra, 1983; Piva, Limonta, Maggi \& Martini, 1984). The effects of the opioids and of their antagonists on gonadotrophin release may be deeply influenced by the endocrine 'milieu' existing at the time of administration (Meites et al., 1979; Bhanot \& Wilkinson, 1983a, b; Kalra \& Kalra, 1983; Gabriel, Simpkins \& Kalra, 1983; Petraglia et al., 1984; Piva, Maggi, Limonta, Motta \& Martini, 1985).

However, there is little indication in the literature on whether the effects that morphine, the opioid peptides and opioid antagonists exert on prolactin secretion might be modified by sex steroid manipulation. The present experiments have been conducted to determine whether castration might influence the prolactin response to morphine administered intraventricularly. The specific opioid receptor antagonist naloxone was used in some experiments to check whether the effects of morphine on prolactin release were due to an activation of opioid receptors and not to a non-specific effect. 


\section{Materials and Methods}

Adult male rats of the Sprague-Dawley strain (Nossan, Correzzana, Milano, Italy) were used. Animals were caged in groups of 5, in rooms with controlled temperature and humidity. The light schedule was $14 \mathrm{~h}$ light and $10 \mathrm{~h}$ darkness (lights on at 06:30 h). Standard pellet food and water were available ad libitum. For the experiments with normal animals, rats of $250 \pm 15 \mathrm{~g}$ body weight were used. For the experiments with castrated animals, groups of male rats were castrated when weighing $160 \pm 10 \mathrm{~g}$; these animals were subsequently kept for 4 weeks in the animal quarters. To achieve the intraventricular injections (i.v.t.) of morphine and naloxone, normal and castrated animals were implanted stereotaxically, 3 days before the experiments, with a guide cannula which was placed in one of the lateral cerebral ventricles. The animals were mounted on a Stoelting stereotaxic instrument model 51.200 under pentobarbitone anaesthesia $(30 \mathrm{mg} / \mathrm{kg}$ i.p.). The head skin was incised and the theca of the skull exposed. A hole was drilled in the theca with a dental drill $1 \mathrm{~mm}$ posteriorly and $1 \mathrm{~mm}$ laterally to the bregma. A 20 -gauge cannula was lowered into the brain to a depth of $5 \mathrm{~mm}$ so that the tip of the needle would reach one of the lateral ventricles; this was confirmed by the flow of a minimal amount of cerebrospinal fluid. The cannula was fixed to the skull with dental cement and plugged with silicone adhesive (Bostik, Milano) to avoid loss of cerebrospinal fluid. The correct location of the cannula was verified at the time of autopsy. Only animals in which the cannula was correctly placed were retained in the study.

Naloxone $\mathrm{HCl}$ was a gift of ENDO Laboratories, Inc., Garden City, NY, U.S.A. Morphine $\mathrm{HCl}$ was obtained from Carlo Erba, Milano, Italy. The doses of each drug and of their combinations were selected on the basis of preliminary experiments. The doses of naloxone and morphine to be injected i.v.t. were dissolved in $10 \mu \mathrm{l} 0.154 \mathrm{M}-\mathrm{NaCl}$ (saline); control animals received i.v.t. injections of $10 \mu \mathrm{l}$ saline. When the i.v.t. treatments had to be performed simultaneously with the two drugs, the dose selected for each drug was dissolved in $5 \mu$ l saline. All i.v.t. injections were performed without any anaesthesia between 16:00 and 18:00 h. To minimize the stress-induced release of prolactin, animals were handled twice a day for 7-10 days before the beginning of each experiment. After i.v.t. injection, control and experimental animals were killed by decapitation at the times indicated in the 'Results'. Blood was collected from the trunk vessels; serum was separated by centrifugation and kept frozen $\left(-20^{\circ} \mathrm{C}\right)$ until assay. Serum concentrations of prolactin were measured with a specific radioimmunoassay procedure (Niswender, Chen, Midgley, Meites \& Ellis, 1969). The interassay variation was $4 \cdot 65 \%$; the intra-assay variation was $2 \cdot 80 \%$. Sensitivity of the assay was $1.5 \mathrm{ng} / \mathrm{ml}$. The data are expressed in terms of NIAMDD-rat RP-1.

The results were statistically analysed by Dunnett's test (1955) for multiple comparisons after one-way analysis of variance.

\section{Results}

Table 1 shows the effects on serum prolactin concentrations of morphine administered i.v.t. to normal and to long-term castrated adult male rats. The dose of morphine selected for these experiments $(200 \mu \mathrm{g} / \mathrm{rat})$ significantly enhanced prolactin release in normal animals at all the times considered. When given i.v.t. a dose of $200 \mu \mathrm{g}$ morphine/rat was totally unable to increase prolactin release in adult castrated male rats at any time considered; serum prolactin concentrations in the animals treated i.v.t. with morphine were not significantly different from those found in the corresponding control animals injected with saline. Saline when injected i.v.t. did not significantly enhance serum prolactin concentrations above those found in implanted non-injected animals. In saline-injected animals there was an apparent decrease of serum prolactin concentration at the later observation times in normal and in castrated rats. However, the values at 20,40 and 60 min were not significantly different from those at $10 \mathrm{~min}$.

Table 1 also shows that naloxone, when given i.v.t. to normal adult male rats, at doses of 7.5 or 
Table 1. Effect of intraventricular (i.v.t.) injections of morphine and naloxone on serum prolactin concentrations in normal and castrated (4 weeks) male rats

\begin{tabular}{|c|c|c|c|c|}
\hline \multirow[b]{2}{*}{ Groups } & \multicolumn{4}{|c|}{ Time after i.v.t. injection } \\
\hline & $10 \mathrm{~min}$ & $20 \mathrm{~min}$ & $40 \mathrm{~min}$ & $60 \mathrm{~min}$ \\
\hline \multicolumn{5}{|l|}{ Normal male rats } \\
\hline Saline $\quad(10 \mu \mathrm{l} / \mathrm{rat})$ & $49 \cdot 27 \pm 8.29(15)$ & $36.19 \pm 4.44(24)$ & $27 \cdot 62 \pm 6 \cdot 16(6)$ & $20.85 \pm 3.05$ \\
\hline Morphine $(200 \mu \mathrm{g} / \mathrm{rat})$ & $* 83.75 \pm 16.80$ (15) & *76.93士 $6.80(27)$ & $* 81.37 \pm 14.08(8)$ & $* 66.91 \pm 7.94(10)$ \\
\hline Naloxone $(7.5 \mu \mathrm{g} / \mathrm{rat})$ & $36.43 \pm 5.81(18)$ & $37.51 \pm 6.22(30)$ & & \\
\hline Naloxone $(15 \mu \mathrm{g} / \mathrm{rat})$ & $36.98 \pm 4 \cdot 10(20)$ & $22.44 \pm 4.68(20)$ & & \\
\hline Morphine $(200 \mu \mathrm{g} / \mathrm{rat})$ & & & & \\
\hline+ naloxone $\quad(7.5 \mu \mathrm{g} / \mathrm{rat})$ & $54 \cdot 81 \pm 7.84(11)$ & $\dagger 36 \cdot 88 \pm 2 \cdot 95(20)$ & & \\
\hline $\begin{aligned} \text { Morphine } & (200 \mu \mathrm{g} / \mathrm{rat}) \\
+ \text { naloxone } & (15 \mu \mathrm{g} / \mathrm{rat})\end{aligned}$ & $45.05 \pm 7.58$ & $+38.45 \pm 7.92(11)$ & & \\
\hline \multicolumn{5}{|l|}{ Castrated male rats } \\
\hline Saline $\quad(10 \mu \mathrm{l} /$ rat $)$ & $41.76 \pm 5.99$ & $41.78 \pm 10.95$ & $24 \cdot 20 \pm 3 \cdot 79(5)$ & $20.56 \pm 1.57$ \\
\hline Morphine $(200 \mu \mathrm{g} / \mathrm{rat})$ & $27.38 \pm 7.44$ (9) & $36 \cdot 44 \pm 11 \cdot 82(8)$ & $39.86 \pm 7.09(5)$ & $29 \cdot 65 \pm 5.54(6)$ \\
\hline
\end{tabular}

Values are mean \pm s.e.m. for the no. of animals in parentheses.

$* P<0.05$ compared with saline-injected animals.

$\dagger P<0.05$ compared with morphine-injected animals.

$15 \mu \mathrm{g} / \mathrm{rat}$, was totally ineffective in significantly modifying prolactin release at 10 or $20 \mathrm{~min}$ after administration. The observations were limited to these time intervals because naloxone is a short-acting drug, which shows its highest activity between 15 and $20 \mathrm{~min}$ after administration (Cicero, Schainker \& Meyer, 1979). Table 1 also shows that the effects of $200 \mu \mathrm{g}$ morphine/rat were decreased by the concomitant i.v.t. administration of naloxone, at the 10 and $20 \mathrm{~min}$ times. The decrease of the morphine effect induced by naloxone was statistically significant at $20 \mathrm{~min}$, i.e. at the time at which naloxone has been reported by others to exert its maximal effect (Cicero et al., 1979).

\section{Discussion}

The results of the present study show that morphine, when given i.v.t. to normal adult male rats, is able to increase serum prolactin concentrations. These data are in agreement with results obtained by previous authors, following systemic (for references, see Meites et al., 1979; Morley, 1981; Clement-Jones \& Rees, 1982) or i.v.t. injections of morphine, the endogenous opioid peptides and their synthetic analogues (Rivier et al., 1977; Chihara et al., 1978; Kato et al., 1978, 1982; Panerai et al., 1981; Van Vugt et al., 1981; Matsushita et al., 1982; Giudici et al., 1984).

The experiments performed in long-term castrated rats clearly show that even the i.v.t. injection of a rather high dose of morphine is totally unable to increase significantly serum prolactin concentrations 4 weeks after orchidectomy. The present observation supports the data (see 'Introduction') that show that morphine, the opioids and their antagonists may lose their ability to influence LH release after castration, if steroid replacement therapy is not provided (Meites et al., 1979; Bhanot \& Wilkinson, 1983a, b; Gabriel et al., 1983; Kalra \& Kalra, 1983; Petraglia et al., 1984; Piva et al., 1985).

There is little information in the literature supporting the view that the absence of testicular steroids might alter the prolactin response to the administration of morphine or other opioids. Goldberg, Conforti \& Spitz (1982) have shown that the i.v.t. administration of $500 \mu \mathrm{g}$ metenkephalin to normal adult male rats causes a significant rise in serum prolactin concentrations and 
that the same treatment results in a much lower release of prolactin in orchidectomized rats. Kato et al. (1982) have found that beta-endorphin induces an increase of plasma prolactin in castrated male rats, which is almost 10 times lower than that observed in normal animals (Kato et al., 1978). Moreover, Forman, Sonntag, Miki, Ramos \& Meites (1981) have reported that the stimulatory effect of morphine on prolactin release is decreased in aged male rats, which are known to have serum testosterone levels lower than those of younger animals. Foresta, Patarnello, Casara, Federspil \& Scandellari (1984) reported that the enkephalin analogue, FK 33,824, significantly increases prolactin levels in normal men and is much less effective in castrated subjects.

It is presently believed that the opioids modify prolactin release through a central nervous system mechanism (Rivier et al., 1977; Matsushita et al., 1982; Giudici et al., 1984), which involves the activation of specific brain receptors of the mu and kappa families (Spiegel, Kouzides \& Pasternak, 1982; Koenig \& Krulich, 1984). The loss of effectiveness of morphine on prolactin secretion induced by orchidectomy may therefore be due to an alteration, induced by castration, of the number or of the binding characteristics of brain mu and kappa receptors. However, the literature on the effects exerted by castration on brain opioid receptors is scanty and controversial. Hahn \& Fishman $(1979,1985)$ have found that the binding of naltrexone, naloxone and diprenorphine to opioid receptors in the rat whole brain is increased by orchidectomy, but Wilkinson, Herdon \& Wilson (1981), Diez \& Roberts (1982) and Cicero, Newman \& Meyer (1983) have found that neither castration nor subsequent androgen replacement therapy modify the binding capacity of the whole brain and of the hypothalamus for a number of opioid ligands. An alternative possibility is that castration might have modified the bioavailability of other brain neurotransmitters involved in the control of prolactin secretion (Müller, Nisticò \& Scapagnini, 1977). There is plenty of evidence indicating that the opioids may modulate the activity of catecholaminergic, serotoninergic and cholinergic systems in the brain (Koenig et al., 1980; Fanjul, De Galarreta \& Meites, 1981; Kalra \& Kalra, 1983; Arita \& Porter, 1984).

In the present series of experiments, it was found that i.v.t. naloxone, when given alone in a dose which totally suppresses the stimulatory effect of morphine is unable to decrease serum prolactin concentrations. The present finding is supported by some data in the literature obtained after systemic administration of naloxone (Martin et al., 1979; Mioduszewski et al., 1982) The failure of naloxone to produce any effect on basal prolactin secretion observed in the present study argues against the existence of a permanent stimulating activity of endogenous opioid peptides on the release of this hormone. As far as we know, the only report in the literature dealing with the effects of naloxone administered i.v.t. on prolactin release is that of Giudici et al. (1984) who showed that i.v.t. injections of naloxone (in doses ranging from 7 to $30 \mu \mathrm{g} / \mathrm{rat}$ ) do not alter prolactin release in normal adult male rats. Chihara et al. (1978), Panerai et al. (1981) and Van Vugt et al. (1981) also used i.v.t. administration of naloxone; they found that i.v.t. injection of naloxone may prevent the stimulation of prolactin secretion induced by beta-endorphin and dynorphin, but the effect of the opioid antagonist given alone was not evaluated.

The present observation that i.v.t. naloxone may counteract the stimulatory effect of morphine on prolactin secretion is in line with several previous reports. Chihara et al. (1978), Panerai et al. (1981), Van Vugt et al. (1981) and Giudici et al. (1984) have reported that i.v.t. injections of naloxone block the release of prolactin induced by morphine, beta-endorphin, dynorphin and dermorphin.

The experiments reported in this paper have been supported by grants of the Consiglio Nazionale delle Ricerche, Roma (through the special projects 'Medicina Preventiva e Riabilitativa', contract no. 84.02467.56.115.08178, and 'Gruppo di Endocrinologia', contract no. 84.00821), and of the Ministero della Pubblica Instruzione. Material for prolactin radioimmunoassay was provided by the Rat Pituitary Hormone Distribution Program of the NIADDKD Bethesda, Maryland, U.S.A. We thank Mrs Paola Assi and Mr Enrico Croce for skilful technical assistance. 


\section{References}

Arita, J. \& Porter, J.C. (1984) Relationship between dopamine release into hypophyseal portal blood and prolactin release after morphine treatment in rats. Neuroendocrinology 38, 62-67.

Bhanot, R \& Wilkinson, M. (1983a) Opiatergic control of LH secretion is eliminated by gonadectomy. Endocrinology 112, 399-401.

Bhanot, R. \& Wilkinson, M. (1983b) Opiatergic control of gonadotropin secretion during puberty in the rat: a neurochemical basis for the hypothalamic 'gonadostat'? Endocrinology 113, 596-603.

Chihara, K., Arimura, A., Coy, D.H. \& Schally, A.V. (1978) Studies on the interaction of endorphins, substance $P$, and endogenous somatostatin in growth hormone and prolactin release in rats. Endocrinology 102, 281-290.

Cicero, T.J., Schainker, B.A. \& Meyer, E.R. (1979) Endogenous opioids participate in the regulation of the hypothalamic-pituitary-luteinizing hormone axis and testosterone's negative feedback control of luteinizing hormone. Endocrinology 104, 1286-1291.

Cicero, T.J., Newman, K.S. \& Meyer, E.R. (1983) Testosterone does not influence opiate binding sites in the male rat brain. Life Sci. 33, 1231-1239.

Clement-Jones, V. \& Rees, L.H. (1982) Neuroendocrine correlates of the endorphins and enkephalins. In Clinical Neuroendocrinology, vol. II, pp. 139-203. Eds G. M. Besser \& L. Martini. Academic Press, New York.

Diez, J.A. \& Roberts, D.L. (1982) Evidence contradicting the notion that gonadal hormones regulate brain opioid receptors. Biochem. Biophys. Res. Commun. 108, 1313-1319.

Dunnett, C.W. (1955) A multiple comparison procedure for comparing several treatments with a control. $J$. Am. Stat. Ass. 50, 1096-1121.

Fanjul, L.F., De Galarreta, C.M.R. \& Meites, J. (1981) Interaction of morphine with the cholinergic system on prolactin release. Proc. Soc. exp. Biol. Med. 166, 542-545.

Foresta, C., Patarnello, T., Casara, D., Federspil, G. \& Scandellari, C. (1984) Interference of gonadal steroids and thyroid hormones on opioid control of prolactin secretion. J. Endocr. Invest. 7 (Supply. 1), 37, Abstr.

Forman, L.J., Sonntag, W.E., Miki, N., Ramos, T. \& Meites, J. (1981) Comparison of the effects of central acting drugs on prolactin release in young and old male rats. Proc. Soc. exp. Biol. Med. 167, 354-358.

Gabriel, S.M., Simpkins, J.W. \& Kalra, S.P. (1983) Modulation of endogenous opioid influence on luteinizing hormone secretion by progesterone and estrogen. Endocrinology 113, 1806-1811.

Giudici, D., D’Urso, R., Falaschi, P., Negri, L., Melchiorri, P. \& Motta, M. (1984) Dermorphin stimulates prolactin secretion in the rat. Neuroendocrinology 39, 236-244.

Goldberg, R., Conforti, N. \& Spitz, I.M. (1982) The effect of methionine enkephalin on prolactin and luteinizing hormone levels in intact and castrated rats. Hormone Metab. Res. 14, 89-92.

Hahn, E.F. \& Fishman, J. (1979) Changes in rat brain opiate receptor content upon castration and testosterone replacement. Biochem. Biophys. Res. Commun. 90, 819-823.

Hahn, E.F. \& Fishman, J. (1985) Castration affects male rat brain opiate receptor content. Neuroendocrinology $41,60-63$.

Kalra, S.P. \& Kalra, P.S. (1983) Neural regulation of luteinizing hormone secretion in the rat. Endocr. Rev. 4, 311-351.

Kato, Y., Iwasaki, Y., Abe, H., Ohgo, S. \& Imura, H. (1978) Effects of endorphins on prolactin and growth hormone secretion in rats. Proc. Soc. exp. Biol. Med. $158,431-436$.

Kato, Y., Hiroto, S., Katakami, H., Matsushita, N., Shimatsu, A. \& Imura, H. (1982) Effects of a synthetic Met $^{5}$-enkephalin analog on plasma luteinizing hormone and prolactin levels in conscious orchidectomized rats. Proc. Soc. exp. Biol. Med. 169, 95-100.

Koenig, J.I. \& Krulich, L. (1984) Differential role of multiple opioid receptors in the regulation of secretion of prolactin and growth hormone in rats. In Opioid Modulation of the Endocrine Function, pp. 89-98. Eds G. Delitala, M. Motta \& M. Serio. Raven Press, New York.

Koenig, J.I., Mayfield, M.A., Coppings, R.J., McCann, S.M. \& Krulich, L. (1980) Role of central nervous system neurotransmitters in mediating the effects of morphine on growth-hormone and prolactin secretion in the rat. Brain Res. 197, 453-468.

Martin, J.B., Tolis, G., Woods, I. \& Guyda, H. (1979) Failure of naloxone to influence physiological growth hormone and prolactin secretion. Brain Res. 168, 210-215.

Matsushita, N., Kato, Y., Shimatsu, A., Katakami, H., Fujino, M., Matsuo, H. \& Imura, H. (1982) Stimulation of prolactin secretion in the rat by alphaneo-endorphin, beta-neo-endorphin and dynorphin. Biochem. Biophys. Res. Commun. 107, 735-741.

Meites, J., Bruni, J.F., Van Vugt, D.A. \& Smith, A.F. (1979) Relation of endogenous opioid peptides and morphine to neuroendocrine functions. Life Sci. 24, 1325-1336.

Mioduszewski, R., Zimmerman, E. \& Critchlow, V. (1982) Effects of morphine dependence, withdrawal and tolerance on prolactin and growth hormone secretion in the rat. Life Sci. 30, 1343-1348.

Morley, J.E. (1981) The endocrinology of the opiates and opioid peptides. Metabolism 30, 195-209.

Müller, E.E., Nisticò, G. \& Scapagnini, U. (1977) Neurotransmitters and Anterior Pituitary Function. Academic Press, New York.

Niswender, G.D., Chen, C.L., Midgley, A.R., Jr, Meites, J. \& Ellis, S. (1969) Radioimmunoassay for rat prolactin. Proc. Soc. exp. Biol. Med. 130, 793-797.

Panerai, A., Casanueva, F., Martini, A., Mantegazza, P. \& Di Giulio, A.M. (1981) Opiates act centrally on GH and prolactin release. Endocrinology 108, 2400-2402.

Petraglia, F., Locatelli, V., Penalva, A., Cocchi, D., Genazzani, A.R. \& Müller, E.E. (1984) Gonadal steroid modulation of naloxone-induced LH secretion in the rat. J. Endocr. 101, 33-39. 
Piva, F., Limonta, P., Maggi, R. \& Martini, L. (1984) Dual effects of opioids in the control of gonadotropin secretion. In Opioid Modulation of the Endocrine Function, pp. 155-169. Eds G. Delitala, M. Motta \& M. Serio. Raven Press, New York.

Piva, F., Maggi, R., Limonta, P., Motta, M. \& Martini, L. (1985) Effect of naloxone on LH, FSH and prolactin secretion in the different phases of the estrous cycle. Endocrinology 117, 766-772.

Rivier, C., Vale, W., Ling, N., Brown, M. \& Guillemin, R. (1977) Stimulation in vivo of the secretion of prolactin and growth hormone by beta-endorphin. Endocrinology 100, 238-241.
Spiegel, K., Kourides, I.A. \& Pasternak, G.W. (1982) Different receptors mediate morphine-induced prolactin and growth hormone release. Life Sci. 31, 2177-2180.

Van Vugt, D.A., Sylvester, P.W., Aylsworth, C.F. \& Meites, J. (1981) Comparison of acute effects of dynorphin and beta-endorphin on prolactin release in the rat. Endocrinology 108, 2017-2018.

Wilkinson, M., Herdon, H. \& Wilson, C.A. (1981) Gonadal steroid modification of adrenergic and opiate receptor binding in the central nervous system. In Steroid Hormone Regulation of the Brain, $\mathrm{pp}$. 253-263. Eds K. Fuxe, J. A. Gustafsson \& L. Wetterburg. Pergamon Press, Oxford.

Received 8 August 1985 